Acta Crystallographica Section A

Foundations of Crystallography

ISSN 0108-7673

\section{International Union of Crystallography Nineteenth General Assembly and International Congress of Crystallography Geneva, Switzerland, 6-15 August 2002}

\section{Introduction and Opening Ceremony}

By invitation of the Israeli Crystallographic Society, the Nineteenth General Assembly and International Congress of Crystallography were held at the Palexpo Conference Center, Geneva, Switzerland, 6-15 August 2002.

The meetings were attended by over 1,950 participants.

The General Assembly and Congress were opened on the evening of 6 August at the Noga Hilton Hotel. The Opening Address by Professor H. SCHENK, President of the IUCr, was followed by Welcoming Addresses by Professor J. BERNSTEIN (Chair of the Organizing Committee) and Professor M. KAFTORY (Chair of the Programme Committee). There followed a musical interlude performed by the Klezmer Pau-Wau. The Ewald Prize was then accepted by Professor M. M. WOOLFSON, who presented the Ewald Address. The evening ended with a Welcoming Reception.

\section{Nineteenth International Congress}

\subsection{Scientific programme}

31 Keynote Lectures, 95 Microsymposia and 14 Open Commission Meetings were held during the morning and late afternoon sessions. The early afternoon sessions were reserved for poster sessions. The abstracts in the published book of Collected Abstracts were prepared from electronic submissions and were also provided on a CD-ROM.

\subsection{Exhibitions}

A commercial exhibition comprising 35 companies and booksellers was organized. Computer terminals to enable e-mail access for all attendees were provided.

\subsection{Social events}

In addition to the Opening Reception, evening entertainments included a student mixer, an Israeli Evening, a Concert, a Gala Dinner and a Closing Ceremony. An evening reception for delegates was organized by the Swiss National Committee for Crystallography. Various excursions were also arranged.

\section{Minutes of the Nineteenth General Assembly}

These Minutes have been prepared by M. H. Dacombe, Executive Secretary, under the authority of S. Larsen, General Secretary and Treasurer of the IUCr and Secretary of the General Assembly.

\subsection{Introduction and list of delegates}

Sessions of the General Assembly were held on the evenings of Wednesday 7 August, Thursday 8 August and Tuesday 13 August. It was not found necessary to meet on Wednesday 14 August, as originally planned. The following attendance list gives the names of official delegates appointed by the Adhering Bodies and the alternates who substituted at one or more sessions. Dates of attendance are given in parentheses for those who were not present at every session. The names are listed by the countries to which the respective Adhering Bodies belong, and the number of votes of the Adhering Body is given in parentheses after the name of the country. The names of the Chairs of the delegations are given in bold where they are known; those of alternates are marked by an asterisk. The Category of Adherence for Czech/Slovak Republics was increased to 2 at the first session. There were no delegates from Bulgaria or Ukraine.

Argentina (1): G. Punte (non-voting)

Australia (3): J. M. Guss, M. A. Spackman, J. W. White

Austria (1): A. Preisinger

Belgium (2): G. H. Evrard, K. Michel

Brazil (3): A. F. Craievich, Y. P. Mascarenhas, I. Torriani

Canada (3): I. D. Brown, L. T. J. Delbaere, G. Ferguson

Chile (1): J. Garin (8 August)

China, People's Republic (4): X. Jin, S. Liu, L. Weng, X. Yao (7 and 8 August)

China, The Academy of Sciences Located in Taipei (2): S. L. Chang,

Yu Wang

Croatia (1): S. Popović

Czech/Slovak Republics (2): J. Kozisek, Z. Šourek

Denmark (1): E. Makovicky, P. Harms* (8 August), J. S. Pedersen* (7 August)

Egypt (1): M. Radwan

Finland (1): T. L. P. Paakkari

France (4): J.-C. Daran, J.-L. Hodeau, R. Kahn, C. Lecomte

Germany (4): W. Depmeier, F. Frey, G. Heger* (13 August), P. Luger,

P. Paufler (7 and 8 August)

Hungary (1): A. Kálmán

India (2): S. K. Sikka, M. Vijayan

Israel (1): M. Harel* (7 and 8 August), J. Sussmann (13 August)

Italy (3): G. Ferraris* (13 August), G. Filippini, C. Mealli (7 and 8 August), D. Viterbo

Japan (4): Y. Kai, M. Sakata, S. Sasaki, N. Yasuoka

Korea (1): S. J. Chung

Mexico (1): J. L. Boldú

The Netherlands (2): B. W. Dijkstra, A. L. Spek

New Zealand (1): G. Clark

Norway (1): B. Fjaertoft-Pedersen

Poland (1): J. Lipkowski (8 and 13 August)

Portugal (1): M. M. R. R. Costa (8 August), D. Aragão (13 August)

Russia (4): M. V. Kovalchuk, D. Yu. Pushcharovsky, V. I. Simonov, S. I. Zheludeva

Serbia (1): S. Stanković

Slovenia (1): I. Leban (7 and 8 August)

South Africa (2): D. Levendis, A. Roodt

Spain (3): S. Gracia-Granda, C. Miravitlles, J. Rius* (13 August), X.

Solans (7 and 8 August)

Sweden (2): A. Liljas, I. Olovsson 
Switzerland (2): G. Chapuis (7 and 13 August), H. Grimmer, H. D. Flack* (8 August)

UK (5): J. Evans, C. Gilmore, R. O. Gould, H. Powell, C. C. Wilson

USA (5): J. Clardy, J. L. Flippen-Anderson, M. L. Hackert, W. Stallings, R. Sweet

Venezuela (1): G. Delgado

Present as members of the Executive Committee: H. Schenk (President), M. Tanaka (Vice-President), S. Larsen (General Secretary and Treasurer), E. N. Baker (Immediate Past President), L. A. Aslanov, M. A. Carrondo, W. L. Duax, H. Fuess (Ordinary Members). M. H. Dacombe was in attendance as Executive Secretary.

\subsection{First Session, Wednesday 7 August 2002, 7:35 p.m.}

(1) Introductory remarks by the President

Professor SCHENK welcomed the delegates and observers. He encouraged delegates to discuss items with him or other members of the Executive Committee.

(2) Procedural matters

In order to verify the list of voting delegates, the President requested the General Secretary to read this list, and asked delegates to indicate their presence when their names were called. (This procedure was repeated at the beginning of each session of the General Assembly.)

Two delegates, one from New Zealand and one from Slovenia, were appointed to act as tellers when votes had to be counted during the Assembly.

\section{(3) Approval of Agenda}

The Agenda and Appendices to the Agenda had been distributed to Secretaries of National Committees in May 2002. The Agenda were approved.

(4) Amendments to Statutes and By-Laws affecting adherence to the Union

The President reported that there were no proposals.

(5) Applications for membership of the Union

The President reported that there were no applications.

(6) Withdrawal of Adhering Bodies

The President reported that the subscriptions from the Adhering Bodies for Argentina and Ukraine were both more than four years in arrears and that their membership of the IUCr had automatically been suspended. The General Assembly was asked to confirm the withdrawal of the Adhering Bodies for Argentina and Ukraine. A. CRAEIVICH asked if it would be possible for these Adhering Bodies to remain as members and M. HACKERT reported that the American Crystallographic Association was planning to start a South American initiative that could perhaps help. This item was postponed to the second session of the General Assembly to allow time for further discussion. See Minute (23).

(7) Changes in names of Adhering Bodies

The changes in names of the Adhering Bodies of Belgium (to the Royal Academies for Science and the Arts of Belgium) and South Africa (to the National Research Foundation) were accepted by the General Assembly.

(8) Changes in Category of Adherence of Adhering Bodies

The change in Category of Adherence of the Adhering Body for the Czech and Slovak Republics (the Regional Committee of Czech and Slovak Crystallographers) from Category I to Category II was approved by the General Assembly.

\section{(9) Approval of Minutes of Eighteenth General Assembly}

The Minutes, which were contained in the published Report of the Eighteenth General Assembly and International Congress of Crystallography [Acta Cryst. (2001), A57, 741-795], were approved and two copies were signed by the President and the General Secretary, in accordance with By-Law 1.13. There were no matters arising from the Minutes.

(10) Amendments to Statutes and By-Laws not affecting adherence to the Union

The President reported that there were no proposals.

(11) Report of Executive Committee

The Report of the Executive Committee on the activities of the IUCr since the Eighteenth General Assembly had been submitted to the National Committees and the Commissions in May 2002, in accordance with Statute 6.8, and follows these Minutes as Annex I, Appendix A. The President selected some highlights from the Report and thanked the members of the Executive Committee for all their work. The Report was accepted without discussion.

(12) Financial Report

A Financial Report, covering the calendar years 1999, 2000 and 2001, had been prepared by the Treasurer and had been submitted to the National Committees and the Commissions in May 2002. The Report follows these Minutes as Annex I, Appendix B.

The Treasurer described the present membership of the Finance Committee and noted that the general trends over the past triennium had been a strong dollar, a strong pound, decreasing interest rates and, since 2000, a weakened and volatile stock market.

The Treasurer presented a plot showing the value of the assets since 1983, net additions/removals during each year and the excess/ deficit of income over expenditure for each year. In recent years, there had been an annual deficit of income over expenditure. This was because part of the assets had been used to finance four essential initiatives: (1) online journals, (2) digitization of back issues, (3) launch of the online-only journal Acta Crystallographica Section E and (4) production of new Volumes and new Editions of International Tables for Crystallography. These initiatives had been successfully completed and had been accompanied by accurate allocation of costs to each activity of the Union and by measures to minimize losses on some existing operations (in particular, Special Issues of the journals and production of Journal of Synchrotron Radiation). The operations of the IUCr were now less vulnerable to exchange-rate fluctuations as the majority of the income and the expenditure was in the same currency (GBP). The online availability of all papers published since 1948 was a major tool to exploit marketing possibilities to reverse the trend of decrease in subscriptions. The activities of the Union had been transformed into a state-of-the-art operation, with a predicted return to an operating surplus in 2002. The investment portfolios were handled by Foreign \& Colonial and Merrill Lynch. There was also a holding in UK Gilts. The Finance Committee had developed a strategy document for the investments with the aims to maximize long-term total return consistent with prudent levels of risk, to review progress periodically against market indices (setting portfolio benchmarks), to re-allocate assets to managers that met the above objectives and annually to review the target ranges.

J. A. KADUK asked whether the Union was under a major financial obligation with respect to the pension scheme for the staff. M. J. COOPER (Convener of the Finance Committee and ex officio member of the Executive Committee) confirmed that this was not the case. The pension funds were separate from the funds of the Union and were handled externally. J. D. BARNES commented that the holding in equities (about $70 \%$ of the portfolio) was high. The Treasurer noted that at this stage we did not need to realize the assets and that until recently the advice from the investment advisers had been to operate at this level. The benchmark introduced in 2002 was to aim for $65 \%$ equities in the longer term (equities still outperformed cash in the long term). J. W. WHITE asked about the 
strategy for marketing online products. The Treasurer replied that the Union was now in an excellent position and many avenues were available (for example, consortial deals). An extensive marketing plan was in place. In response to a question from J.-L. HODEAU concerning the influence on impact factors, the Treasurer noted that these were monitored closely - especially for the effect of crystallization papers on Acta Crystallographica Section D.

The General Assembly thanked the Treasurer for her clear explanations and accepted the Financial Report with applause.

(13) Ewald Prize

Details of the Prize, awarded to Professor M. M. Woolfson at the Opening Ceremony, and the citation are given in Annex I, Appendix C.

The Selection Committee was thanked for its work.

(14) Commission on Journals

The Report of the Commission on Journals had been distributed to the National Committees and the Commissions in May 2002 and is reprinted in Annex I, Appendix D.

The Chair noted that the Co-editors formed a very active group and a productive meeting had been held in Villigen immediately prior to the Congress.

The President commented that he was sure that P. P. Ewald would be proud of the journals as envisaged in his original Editorial in Acta. He thanked all concerned for their work. The Report was accepted by the General Assembly.

\section{(15) Commission on International Tables}

The Report by the Chair of the Commission on International Tables had been distributed to the National Committees and the Commissions in May 2002 and is reprinted in Annex I, Appendix D.

The Chair reported that there were nine active volumes and that he felt his work was complete.

The President thanked the Chair for all his work with the secondgeneration of International Tables and commented that he could be very proud of the Commission under his guidance. The Report was accepted with applause by the General Assembly.

(16) Committee on Electronic Publishing, Dissemination and Storage of Information

The Report of the Chair of the Committee on Electronic Publishing, Dissemination and Storage of Information had been distributed to the National Committees and the Commissions in May 2002 and is reprinted in Annex I, Appendix E.

The President commented that this Committee had played a major role in bringing the publications into the modern world and thanked the Chair for his work.

(17) Committee for the Maintenance of the CIF Standard (COMCIFS)

The Report of the Chair of the Committee for the Maintenance of the CIF Standard (COMCIFS) had been distributed to the National Committees and the Commissions in May 2002 and is reprinted in Annex I, Appendix F.

The Chair asked for people interested in becoming involved with the development of programs that read CIFs and use the dictionaries to contact him.

The President thanked the Chair for his work.

(18) Committee on Crystallographic Databases

The Report of the Chair of the Committee on Crystallographic Databases had been distributed to the National Committees and the Commissions in May 2002 and is reprinted in Annex I, Appendix G.

\section{(19) Promotion Committee}

The Report of the Chair had been distributed to the National Committees and the Commissions in May 1999 and is reprinted in Annex I, Appendix H.
The Chair reported that following the appointment of A. J. Sharpe as Promotions Officer there was a much more professional approach to marketing and promoting the activities of the Union.

The President thanked the Chair for his work.

(20) IUCr Newsletter

The Report of the Editor of the IUCr Newsletter had been distributed to the National Committees and the Commissions in May 2002 and is reprinted in Annex I, Appendix I.

W. L. DUAX (the Editor of the Newsletter) noted that the number of countries represented in the Newsletter had increased in the triennium and he thanked all the contributors.

The President thanked the Chair for his work.

(21) IUCr/Oxford University Press Book Series

The Report of the Chair had been distributed to the National Committees and the Commissions in May 2002 and is reprinted in Annex I, Appendix J.

(22) Non-publishing Commissions

The reports of the Commissions on their activities since the Eighteenth General Assembly had been distributed to the National Committees and the Commissions in May 2002. The reports are reprinted in Annex I, Appendix D.

The reports were taken as read, but the Chair of each Commission, or his or her alternate, accepted the invitation of the President to say a few words about future developments and to answer any questions.

The President thanked all the Chairs for their work. In particular, he noted that S. C. Abrahams, who had been unable to attend the Congress, wished to retire as Chair of the Commission on Crystallographic Nomenclature at this General Assembly. He had been Chair since 1978 and the General Assembly thanked him with applause for all the important work he had done for the Union.

The General Assembly accepted all the reports that had been received on the activities of the non-publishing Commissions.

The President then adjourned the session at 9:45 p.m.

\subsection{Second Session, Thursday 8 August 2002, 6:45 p.m.}

(23) Withdrawal of Adhering Bodies (continued)

The President confirmed that according to Statutes 5.12 and 9.6 it was not necessary for the General Assembly to cancel the membership of Argentina and Ukraine at this stage. As various initiatives were being planned to help countries experiencing financial difficulties, the General Assembly agreed that further discussion should be postponed until 2005. This decision was greeted with applause.

(24) Proposal for new Commissions

The President reported that a formal proposal had been received to establish a Commission on Inorganic and Mineral Structures. The Executive Committee had considered the terms of reference and proposed membership and recommended that the Commission should be established.

G. FERRARIS and D. Yu. PUSHCHAROVSKY spoke in support of the proposal and the General Assembly approved the formation of a Commission on Inorganic and Mineral Structures.

(25) Review of existing Commissions

The President reported that the Executive Committee had considered the work of the Commissions and had no recommendations to modify or discontinue any of the Commissions. He noted that although there was no report from the Chair of the Commission on XAFS, and there had been little contact for two years, the Executive Committee considered this to be an important Commission that should continue. 
(26) Determination of number of elected members of each Commission

In accordance with Statute 5.10( $d)$, the Assembly had to determine the number of persons to be elected on the Commissions until the Twentieth General Assembly; these numbers did not include Chairs, Co-editors or ex officio members. The numbers of elected members approved by the General Assembly (Chairs not included) are set out below:

1. Commission on Journals

2. Commission on International Tables

3. Commission on Aperiodic Crystals

4. Commission on Biological Macromolecules

5. Commission on Charge, Spin and Momentum

Densities

6. Commission on Crystal Growth and Characterization of Materials

7. Commission on Crystallographic Computing

8. Commission on Crystallographic Nomenclature

9. Commission on Crystallographic Teaching

10. Commission on Electron Diffraction

11. Commission on High Pressure

12. Commission on Inorganic and Mineral Structures

13. Commission on Neutron Scattering

14. Commission on Powder Diffraction

15. Commission on Small-Angle Scattering

16. Commission on Structural Chemistry

17. Commission on Synchrotron Radiation

18. Commission on XAFS

(27) Reports of Representatives on Regional and Scientific Associates

In accordance with Statute 8.5, the reports of the Representatives on Regional and Scientific Associates had been circulated with the Agenda papers in May 2002. These reports are reprinted as Annex I, Appendix L.

S. K. SIKKA reported that the satellite powder diffraction meeting of the fourth AsCA meeting in Bangalore, India, in 2001 had been postponed until February 2002. C. LECOMTE reported that Morocco had become a member of the ECA and it was hoped that more African countries would join in due course.

All the reports were accepted.

(28) Reports of Representatives on bodies not belonging to the Union

In accordance with Statute 8.5, the reports of the Representatives had been circulated with the Agenda papers in May 2002. These reports are reprinted as Annex I, Appendix M.

All the reports were accepted.

(29) Sponsorship of meetings: Sub-committee on the Union Calendar

The Report of the Chair had been distributed to the National Committees and the Commissions in May 2002 and is reprinted in Annex I, Appendix K.

The Chair (H. FUESS) and the members of the Committee were thanked with applause for their work.

(30) Confirmation of date and place of Twentieth General Assembly

The invitation from the National Research Council and the Italian National Committee for Crystallography to hold the Congress and General Assembly in Florence, Italy, 23-30 August 2005, which had been preliminarily accepted in 1999, was formally accepted.

(31) Preliminary consideration of date and place of Twenty-First General Assembly
In accordance with By-Law 1.3, the General Assembly could give preliminary consideration to the place of the next but one General Assembly, namely the Twenty-First General Assembly to be held in 2008. The President announced that an invitation had been received from the Science Council of Japan and the Crystallographic Society of Japan to hold the Congress in Osaka, Japan. He reported that the Executive Committee had considered the application and found it to be in order. Indeed, he and the General Secretary had visited the proposed site and found it to be ideal. M. SAKATA presented the formal invitation.

The General Assembly gave preliminary acceptance to the invitation to hold the Twenty-First General Assembly in 2008 in Japan. The decision was greeted with applause.

(32) Determination of general policy and timetable for period to Twentieth General Assembly

There were no comments on this item.

(33) Preliminary consideration of activities for period 2005-2008. There were no comments on this item.

(34) Budget estimates for period to Twentieth General Assembly: determination of unit contribution

These budget estimates had been distributed with the Agenda papers and are printed as Annex I, Appendix $\mathrm{N}$ to these Minutes.

The General Assembly accepted the budget estimates and approved the recommendation of the Executive Committee to continue the unit contribution unchanged, at CHF 1,000, for the years 2003, 2004 and 2005.

(35) Confirmation of appointments of Editors of publications of the Union

In accordance with Statute 7.1, the initial appointments and the reappointments of the Editors of the publications of the IUCr were made by the Executive Committee and were subject to confirmation by the General Assembly.

The Assembly unanimously confirmed the following appointments and reappointments for the period of three years:

Editor-in-Chief of Acta Crystallographica: J. R. Helliwell (UK)

Editor of Section A of Acta Crystallographica: D. Schwarzenbach (Switzerland)

Editor of Section B of Acta Crystallographica: C. P. Brock (USA) Editor of Section $C$ of Acta Crystallographica: G. Ferguson (Canada)

Editor of Section D of Acta Crystallographica: J. P. Glusker (USA) [from January 2003, E. N. Baker (New Zealand) and Z. Dauter (USA) succeeded J. P. Glusker as Joint Editors]

Editors of Section E of Acta Crystallographica: W. Clegg (UK) and D. G. Watson (UK)

Editor of Journal of Applied Crystallography: G. Kostorz (Switzerland)

Editors of Journal of Synchrotron Radiation: A. Kvick (France), D. M. Mills (USA) and T. Ohta (Japan)

General Editor of International Tables and Editor of Volume A: Th. Hahn (Germany)

Editor of Volume B: U. Shmueli (Israel)

Editor of Volume C: E. Prince (USA)

Editor of Volume D: A. Authier (France)

Editors of Volume E: V. Kopsky (Czech Republic) and D. B. Litvin (USA)

Editors of Volume F: M. G. Rossmann (USA) and E. Arnold (USA)

Editors of Volume G: S. R. Hall (Australia) and B. McMahon (UK)

Editors of Volume A1: H. Wondratschek (Germany) and U. Müller (Germany) 
At this point, the President explained how the choices had been made for the Executive Committee nominations for Officers of the Union. Over 25 suggestions had been received from National Committees but there could only be three new six-year appointments and, possibly, one three-year appointment. The principles followed were primarily to ensure fair geographic and scientific (chemical, physical, biological, materials science) representations. The single nomination made for the possible three-year appointment would ensure valuable input from South America, which had so far not been represented on the Executive Committee.

The President adjourned the session at 8:15 p.m.

\subsection{Third Session, Tuesday 13 August 2002, 7:30 p.m.}

The President reported that J. L. Flippen-Anderson would be the Editor of the IUCr Newsletter from August 2002. This announcement was greeted with applause. The retiring Editor W. L. DUAX was thanked with applause by the General Assembly.

(36) Election of Chairs and members of Commissions

The nominations made by the Executive Committee for the Chairs and members of Commissions, after consultation with the Commissions through their Chairs, had been notified to delegates.

J. LIPKOWSKI noted that there were no nominations for crystallographers from Poland. The President reported that none had been received from the National Committee. He encouraged those who felt their region to be under-represented to contact the Commission Chairs to discuss the possibility of appointing a consultant. He explained that appointment of a consultant simply required the recommendation of the Chair of the Commission and the approval of the President.

Since no other nominations had been made by the delegates, the persons recommended by the Executive Committee were considered elected.

The current full memberships of all the Commissions, including the ex officio members, together with the addresses of the Chairs, are given as Annex III.

(37) Election of Representatives on bodies not belonging to the Union and on Regional and Scientific Associates

The nominations made by the Executive Committee for those Representatives to be elected by the General Assembly had been notified to delegates. As no other nominations were made, these persons were considered elected. [It had not been possible to contact the person nominated to be the IUCr Representative to the ICSU Committee on Space Research (COSPAR). Subsequently, J. M. Garcia-Ruiz and R. Delhez (alternate) were appointed by the Executive Committee.]

The names and addresses of the Representatives of the Union, including those appointed ex officio, are given in Annex III.

(38) Election of Officers of the Union

The nominations made by the Executive Committee for Officers of the Union had been included in the Agenda papers distributed in
May 2002. W. L. Duax (USA) was nominated for President, L. A. Aslanov (Russia) for Vice-President and S. Larsen (Denmark) for General Secretary and Treasurer. Five nominations were made for the three six-year vacancies for Ordinary Members: G. Heger (Germany), C. Miravitlles (Spain), Y. Ohashi (Japan), I. Robinson (USA) and M. Vijayan (India). One nomination was made for the possible three-year vacancy for an Ordinary Member: I. Torriani (Brazil). J. L. Flippen-Anderson (USA), J. A. K. Howard (UK) and D. Viterbo (Italy) were nominated by the delegates for the six-year vacancies for Ordinary Members. Elections for three Ordinary Members for the normal six-year term were held by secret ballot. The following nominees were elected:

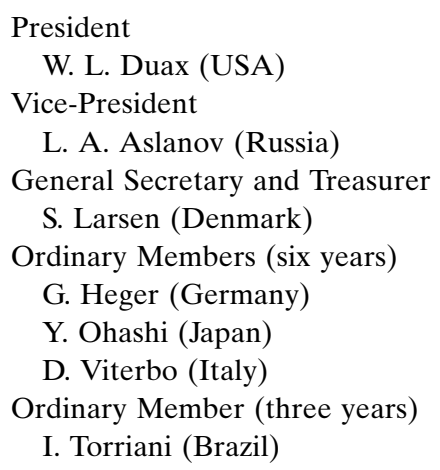

The President congratulated the new members of the Executive Committee and individually thanked those who would be retiring. There had been many long and difficult discussions about important problems during the triennium and their input had been invaluable.

(39) Any other business

Y. EPELBOIN encouraged delegates to update their entries in the World Directory of Crystallographers.

As there was no need for the final session of the General Assembly that had been scheduled for Wednesday 14 August, the President declared the Nineteenth General Assembly closed at 8:55 p.m.

\section{Closing Ceremony, Thursday 15 August 2002}

J. BERNSTEIN (Chair of the Organizing Committee) thanked all involved with making the Congress a success. Three IUCr Poster Prizes in Chemical Crystallography for Younger Scientists sponsored by the Cambridge Crystallographic Data Centre were presented. The Oxford Cryosystems Poster Prize was also presented.

W. L. DUAX, the new President, congratulated those from Israel and Switzerland for making the Congress such a success. He thanked the retiring President (H. SCHENK) for the way he had handled some difficult situations. He envisaged no major changes in the next triennium but would do his best to maintain the health of the Union and its publications and to encourage new countries to join. He then declared the Nineteenth General Assembly and Congress closed. 